\title{
PENGARUH MAQASHID SYARIAH \\ TERHADAP FIQH MUAMALAH DAN FATWA \\ DALAM MEWUJUDKAN MODERASI ISLAM
}

\author{
Khairan Muhammad Arif \\ Khairanmarif.fai@uia.ac.id \\ (Dekan Fakultas Agama Islam UIA Jakarta)
}

\begin{abstract}
Abstrak
Ilmu Maqashid Syari'ah secara umum dapat diartikan dengan pengetahuan yang komprehensif tentang tujuan-tujuan atau maksud dari pembuat Syari'ah yang diturunkan kepada manusia, dimana semua ajaran syariah adalah maslahat seluruhnya dan hikimah seluruhnya bagi manusia. Maksud dan tujuan syari'ah tersebut dapat diidentifikasi secara langsung ataupun melalui studi yang mendalam terhadap teks-teks syari'ah.

Penelitian ini bertujuan mengungkap dan mengeksplor nilai-nilai Maqashid Syari'ah dan pengaruhnya terhadap Fiqh Muamalah dan Fatwa dalam mewujudkan Moderasi Islam, sehingga semua warna mumalah dan fatwa menghadirkan Moderasi Islam. Metode penelitian ini menggunakan kajian kepustakaan (Library Risearch) dengan memberikan analisis dan kesimpulan terhadap konsep dan data-data yang terkait variable penelitian ini.

Hasil Penelitian ini adalah memberikan informasi dan pengetahuan bahwa Maqashid Syari'ah akan menghindarkan umat Islam dari paham dan sikap ekstrem dalam memahami nash-nash agama. Penelitian ini juga memberikan konsep yang konsep yang valid dan utuh tentang fiqh nushus atau (metode memahami Nash Syariah) yang dapat membuktikan bahwa Syari'at Islam itu adalah moderat (wasathiy).

Kata Kunci: Maqashid, Syariah, Muamalah, Moderasi
\end{abstract}

\section{A. Pendahuluan}

Hubungan Maqashid Syariah dengan Moderasi Islam, adalah hubungan yang sangat kuat dan saling memengaruhi. Mengapa demikian? Karena moderasi Islam selalu memperhatikan dan diikat dengan tujuan dan hikmah Syariah secara umum. Tidak ada moderasi, keadilan, keseimbangan dan konsistensi dalam syariah tanpa maqashid syariah, sebaliknya setiap hukum dalam Islam akan mengandung moderasi, keadilan dan maslahat bagi umat, bila berlandaskan maqashid syariah.

\section{B. Pengertian Maqashid As-Syariah}

Secara bahasa maqashi adalah kata jamak dari maqshad yang berarti "tujuan yang diarahkan semua sarana untuk mencapainya" ${ }^{1}$. Adapun secara Istilah, para Ulama terdahulu seperti Imam Syatibiy yang sering disebut sebagai Syekhnya para Ulama Maqashid, tidak memberikan definisi yang final tentang pengertian maqashid syariah. Namun Syekh At-Thahir bin Asyur memberikan pengertian maqashid syariah sebagai berikut:

“Maqashid syar'iyah secara umum adalah makna-makna, atau nilai-nilai dan hikmahhikmah yang dapat ditangkap dan diperhatikan dan diketahui dari pembuat syariah (Allah)

\footnotetext{
1 Muhammad Abdul Athi Muhammad Ali, Al-Maqashid As-Syar'iyah watsaruha fil fiqhil Islami, (Kairo: Darul Hadits, 2007), hal 13
} 
dalam setiap kondisi syariah atau hukum, dimana perhatian atau pengetahuan tersebut tidak spesifik hanya pada faktor tertentu dari sebuah keadaan dari hukum-hukum syariah, akan tetapi juga termasuk pada karakteristik syariah dan tujuannya yang umum, serta nilai-nilai syariah yang harus mendapat perhatian. Bahkan termasuk pada makna-makna yang mengandung hikmah yang tidak dapat diperhatikan dan diketahui dalam semua hukum syariah, namun dapat diperhatikan dan dilihat dari factor yang lain"2.

Ilal Al-Fasi juga seorang Ulama maqashid yang terkenal, beliau mendefinisikan maqashid syariah adalah "Tujuan dari syariah dan rahasianya yang ditetapkan oleh pembuat syariah dari setiap hukum dalam semua hukum-hukumnya" ${ }^{3}$. Ahmad Ar-Raisuni dalam bukunya yang sangat menojol dalam ilmu maqashid bejudul "Nadzariyatul Maqashid indal Imam As-Syatibi", mendefinisikan "Maqashid As-syariah adalah tujuan-tujuan yang ditetapkan oleh syariat, agar dapat dicapai dan direalisasikan dalam rangka mewujudkan maslahat hamba"4.

Yusuf Al-Qardhawi mendefinisikan Maqashid syariah dalam bukunya "Dirasah fi Fiqh Maqashid As-Syariah, bainal Maqashid Al-Kulliyah wa An-Nushus Al-Juz'iyah". Bahwa "Maqashid As-syariah adalah tujuan-tujuan yang dituju dan dimaksud oleh nash-nash, berupa perintah-perintah dan larangan serta hal-hal yang dimubahkan (dibolehkan), dimana hukumhukum praktis dan parsial berusaha mewujudkannya dalam kehidupan para mukallaf (orang yang dibebani hukum), baik dalam kehidupan individu, keluarga, Komunitas maupun umat" ${ }^{5}$.

Dari semua definisi maqashid syariah di atas dapat dismpulkan bahwa "Maqashid Syariah adalah Tujuan, Hikmah atau maksud yang terkandung dari Nash-nash syariah (AlQur'an dan As-Sunnah) dimana tujuan, maksud dan hikmah tersebut mengandung maslahat bagi para mukallaf yang dapat diwujudkan dalam kehidupan baik secara invidu, keluarga, masyarakat dan umat di dunia dan akhirat".

Jadi maqashid syariah adalah ilmu yang membahas tentang tujuan syariah Islamiyah yang ada dalam teks-teks Al-Qur'an dan Hadits, tujuan dan hikmah yang dapat dilihat dan diketahui oleh manusia, sementara menurut At-Thahir bin Asyur juga temasuk pada tujuan dan hikmah syariah yang tidak dapat diperhatikan, dilihat dan diketahui. Para Ulama maqashid sepakat bahwa semua tujuan dan hikmah dari syariah pasti mengandung maslahat bagi hamba di dunia dan akhirat

\section{Pengertian dan Karakteristik Syariah}

\footnotetext{
2 Muhammad At-Thahir bin Asyur, Maqashid As-Syari'ah Al-Islamiyah, (Kairo: Daar As-Salam, 2006), hal 49

3 Muhammad Abdul Athi Muhammad Ali, Al-Maqashid As-Syar'iyah watsaruha fil fiqhil Islami, (Kairo: Darul Hadits, 2007), hal 14

4 Ibid, hal 14

5 Yusuf Al-Qardahwi, Dirasah fi Fiqh Maqashid Syari'ah, bainal maqashid al-kulliyah wa an-nusushus al-juz'iyah, (Kairo: Dar As-Syuruq, cet ke-2 2007), hal 20
} 
Kata syariah telah dipakai oleh umat Islam bahkan umat lain untuk menunjukkan islam atau ajaran Islam. Kata Syariah telah menjadi bahasa Indonesia dipakai sehari-hari oleh umat Islam dalam berbagai hal, termasuk dalam ekonomi, bisnis dan sebagainya. Syariah adalah jalan, manhaj dan pedolam hidup manusia menuju Allah swt, baik terkait hubungan manusia dengan Allah, manusia dengan Rasul-Nya serta manusia dengan manusia harus dipahami dengan benar, objektif, adil, proporsional dan seimbang, sehingga melahirkan pengamalan yang rahamatan lilalamin.

Syariah Islam selain telah menjadi Istilah yang familier dalam kehidupan umat dan bangsa Indonesia, juga telah menjadi semacam momok dan bermakna negative bagi sebagian orang, yang diracuni opini buruk tentang syariah islam yang rabbani dan penuh rahmat ini. Istilah penegakkan syariah menjadi menakutkan bagi barat, antek barat bahkan umat Islam sendiri karena problem pemahaman, sikap dan implementasi ajaran syariah yang keliru dan ekstrem atau sebaliknya liberal.

Pembahasan tentang syariah menjadi penting, dalam perspektif moderasi Islam untuk meluruskan dan memberikan informasi yang benar, shahih dan objektif serta adil tentang syariah yang lurus dan suci ini. Pemahaman yang benar tentang syariah dalam masalah Ibadah, Muamalah, maqashid, karakteristik dan implementasinya dalam kehidupan umat akan memberikan sikap moderat dalam bersyariah.

\section{Pengertian Syariah}

Secara Bahasa Syariah dalam Kamus bahasa adalah "Tempat mengalirnya air untuk diminum". Kata ini biasanya dipakai oleh orang Arab menunjukkan "jalan yang lurus"6. Menurut Ar-Raghib Al-Ashfahani adalah "menapaki atau berjalan pada jalan yang jelas. Seperti anda berkata: "Aku jalankan dia pada jalan itu", sesuai firman Allah: "Kami jadikan baginya syariah dan manhaj" (QS. Al-Maidah: 46). Juga bermakna apa yang diikatkan pada manusia dari ajaran agama untuk ditaatinya, sesuai firman Allah: "Kemudian Kami jadikan engkau berada dalam syariah dan perintah, maka ikutilah" (QS. Al-Jatsiyah: 18) dan firman Allah: "Telah disyariahkan bagimu agama.."(QS. As-Syura: 13). Jadi syariah dalam tinjauan bahasa atau etimologi adalah "jalan yang jelas, agama dan sistem hidup manusia dari Allah swt".

Menurut pengertian istilah atau terminolgi, Mahmud Syalthut dalam bukunya yang sangat terkenal "al-Islam Akidah wa Syariah", bahwa syariah adalah nama dari sebuah sistem dan hukum yang diberikan oleh Allah swt, atau ditetapkan oleh Allah dasar-dasarnya dan mewajibkan setiap muslim melaksanakannya, untuk menata diri mereka dengannya, terkait hubungan mereka dengan Allah swt dan hubungan mereka dengan manusia. Dimana hubungan ini terdiri dua factor:

Pertama, terkait dengan masalah pendekatan diri manusia dengan Tuhannya, mengagungkan-Nya serta sebagai bukti kebenaran imannya pada-Nya dan keyakinan atas pengawasan Allah padanya. Faktor inilah yang disebut dengan Ibadah.

Kedua, faktor yang terkait dengan maslahat hidup manusia, dan mencegah mudharat atau bahaya dalam hidupnya baik pada dirinya dan orang lain, dengan cara mencegah

\footnotetext{
${ }^{6}$ Fairuz Abadziy, Al-Qamus Al-Muhith, (Beirut: Muassasah Ar-Risalah, tt), hal 946
} 
kezaliman yang dengannya kehidupan manusia menjadi aman dan tenteram, maka inilah disebut dengan muamalah"7.

Adapun Yusuf Al-Qardhawi menjelaskan makna syariah seperti yang dikenal saat ini, dapa dibagi menjadi dua pengertian:

Pertama: Syariah dalam pegertian luas adalah agama seluruhnya, terkait dengan akidahnya, syariahnya, akhlak, hukum dan muamalahnya. Dalam arti bahwa Syariah meliputi pokok dan cabang agama Islam, baik keyakinan maupun amaliyahnya, teori dan prakteknya, yang meliputi iman dan akidah dalam semua dimensinya, yang bersifat ilahiyah, kenabian dan hal-hal ghaib lainnya sebagaimanan syariah meliputi semua masalah Ibadah, seluruh masalah muamalah dan akhlak budi pekerti yang dibawa oleh risalah Islam dalam Al-Qur'an dan AsSunnah yang dijelaskan oleh para Ulama akidah, fiqh dan akhlak.

Kedua: Syariah dalam pengertian sempit, adalah semua hal yang terkait dengan sisi perundang-undangan atau hukum-hukum syariah yang bersifat praktis dalam agama, seperti ibadah dan muamalah yang meliputi hubungan dengan Allah dan penghambaan pada-Nya, masalah keluarga atau ahwal syakhsiyah, masalah sosial dan umat Islam, masalah Negara dan pemerintahan serta masalah hubungan internasional. Inilah sisi syariah yang dibahas dalam ilmu Fiqh dan mazhabnya" 8 .

Manna' Al-Qathan mendefiniskan Syariah dengan "Apa saja yang diasyariahkan oleh Allah swt kepada hamba-Nya berupa akidah, Ibadah, Akhlak, muamalah dan system kehidupan dengan cabang-cabangnya yang bermacam-macam dalam rangka mewujudkan kebahagiaan hidup manusia di dunia dan akhirat"9 .

\section{Karakteristik Syariah dalam pandangan Washathiyah}

Salah satu kelebihan pemikiran moderasi Islam adalah mampu memahami dan mengimplementasikan karakteristik Islam dalam kehidupan umat, bahwa Islam dengan karakteristiknya yang mulia, tinggi dan unik, telah memberikan bahyak hikmah, keunggulan dan keutamaan yang luar biasa dalam kehidupan umat Islam dan dunia. Diantara karakteristik Islam secara umum menurut para Ulama adalah:

\section{a. Berorientasi Tuhan (ar-rabbaniyah)}

Salah satu karakteristik utama Islam dan syariahnya adalah berketuhanan atau berorientasi rabb Allah SWT (rabbaniyah) dan tidak mengenal tuhan lain selain-Nya. Maksud dari karakteristik ini adalah bahwa syariah Islam dalam bentuk ibadah, muamalah, hukum dan perundangannya, seluruhnya dalam rangka mengenalkan dan membimbing manusia bahwa Allah adalah Rabb seluruh alam. Semua konsep dan implementasinya dalam rangka mengajak manusia menuju Allah SWT. Tidak ada syariah yang bertentangan dengan maksud dan tujuan Allah menciptakan manusia dan tidak ada ajaran syariah yang menjauhakn manusia dari Allah.

Syariah Islam berbeda dengan agama dan ideology lain yang bersumber dari manusia, maka syariah Islam seluruhnya bersumber dari Allah SWT yang Maha Pencipta. Tidak ada

\footnotetext{
${ }^{7}$ Mahmud Syalthut, Al-Islam Akidah Wa Syariah, (Kairo: Dar As-Syuruq, cet ke-19, 2001), hal 73

8 Yusuf Al-Qardahwi, Dirasah fi Fiqh Maqashid Syariah, bainal mawashid al-kulliyah wa an-nusushus aljuz'iyah, hal 19-20

${ }^{9}$ Manna' Al-Qathan, At-Tasyri' wal Figh Al-Islamiy, (Beirut: Muassasah Ar-Risalah, cet. Ke-8, 1987), hal 438
} 
syariah Islam yang dibentuk dan didominasi oleh akal dan logika manusia kecuali sebagai alat untuk memahami ajaran-ajarannya. Demikian pula tujuan syariah Islam, seluruhnya mengarah dan bertujuan mencapai keridha'an Allah SWT. Seluruh ajarannya, konsepnya, metode dan manhajnya bersumber dari Allah SWT.

Rabbaniyah syariah Islam tidak mengenal sekularisasi, memisahkan antara syariah dengan Negara dan kehidupan dunia, politik, ekonomi, hukum dan sebagainya. Syariah menyatukan dan mengharmoniskan manusia dengan Tuhannya dan mengenalkan mereka hak-hak Allah pada mereka dan kewajiban mereka pada Allah SWT. Syariah mengajarkan Allah SWT adalah pencipta, pengatur, pembimbing, pemberi dan penerima taubat dan do'a, sehingga seluruh kehidupan manusia untuk mengabdi, tunduk dan menyembah kepada Allah Allah SWT.

"Katakanlah (Muhammad), "Sesungguhnya shalatku, ibadahku, hidupku dan matiku hanyalah untuk Allah, Tuhan seluruh alam. tidak ada sekutu bagi-Nya; dan demikianlah yang diperintahkan kepadaku dan aku adalah orang yang pertama-tama berserah diri (muslim)." (QS. Al-An'am: 162-163).

Rabbaniyah syariah Islam adalah ajaran, hidayah, hukum dan pedoman hidup manusia yang telah ada ketika manusia ada, untuk membimbing seluruh manusia. Syariah ini diajarkan dan disosialisasikan para Nabi dan Rasul yang diutus oleh Allah setiap zaman dari Nabi Adam, Idris, Nuh, Ibrahim, Musa, Daud, Isa Alaihim As-salam sampai pada Nabi terakhir Muhammad SAW.

"Dia (Allah) telah mensyariatkan kepadamu agama yang telah diwasiatkan-Nya kepada Nuh dan apa yang telah Kami wahyukan kepadamu (Muhammad) dan apa yang telah Kami wasiatkan kepada Ibrahim, Musa dan Isa yaitu tegakkanlah agama (keimanan dan ketakwaan) dan janganlah kamu berpecah belah di dalamnya. Sangat berat bagi orang-orang musyrik (untuk mengikuti) agama yang kamu serukan kepada mereka. Allah memilih orang yang Dia kehendaki kepada agama tauhid dan memberi petunjuk kepada (agama)-Nya bagi orang yang kembali (kepada-Nya)". (QS. As-Syura: 13).

\section{b. Berperikemanusiaan (al-Insaniyah)}

Kemanusiaan atau Insaniyah maksudnya adalah, bahwa syariah Islam sesuai dan selalu mengakomodir semua kebutuhan dan karakter manusia. Pembebanan ibadah, hukum, perintah dan larangan dalam syariah Islam pasti sesuai dan selaras dengan kemampuan dan kebutuhan manusia. Tidak ada syariah yang bertentangan dengan kemanusiaan dan tidak ada syariah yang tidak mengandung maslahat manusia, karena syariah Islam tidak diciptakan oleh Allah dengan sia-sia, hampa dan tanpa manfaat dan tujuan. Allah berfirman "Dan Kami tidak menciptakan langit dan bumi dan apa yang ada di antara keduanya dengan sia-sia. Itu anggapan orang-orang kafir, maka celakalah orang-orang yang kafir itu karena mereka akan masuk neraka". (QS. Shad: 27).

Insaniyah syariah Islam berakna bahwa tidak ada ajaran di dunia ini yang lebih lengkap, sempurna dan komprehensif menjelaskan tentang hakikat kehidupan manusia selain syariah Islam. Tidak ada kitab suci dan ideologi di dunia ini yang lebih unggul dan futuristic menjelaskan kehidupan manusia, baik sumber materi penciptaannya, proses terjadinya, karakteristiknya, kewajiban-kewajibannya dan kemana akan dikembalikan kehidupan mereka 
selanjutnya, selain Al-Qur'an yang menjadi sumber utama syariah, dan dijelaskan dalam surat yang bernama Al-Insan (manusia). Allah berfirman:

"Bukankah pernah datang kepada manusia waktu dari masa, yang ketika itu belum merupakan sesuatu yang dapat disebut?. Sungguh, Kami telah menciptakan manusia dari setetes mani yang bercampur yang Kami hendak mengujinya (dengan perintah dan larangan), karena itu Kami jadikan dia mendengar dan melihat. Sungguh, Kami telah menunjukkan kepadanya jalan yang lurus; ada yang bersyukur dan ada pula yang kufur". (QS. Al-Insan:

Insaniyah syariah Islam juga bermakna bahwa ajaran, pedoman dan panduan hidup manusia, yang diturunkan oleh Allah untuk manusia dan lingkungannya, disesuaikan dengan akal, hati, emosional, fitrah dan fisiknya. Sehingga tidak ada ajaran syariah baik konsep maupun implementasinya yang tidak dapat dimengerti, dirasakan dan diamalkan oleh manusia. Seluruh perintah dan larangannya telah dimudahkan dicocokkan dan dikoneksikan oleh Allah SWT dengan kemampuan manusia dan kemanusiaannya. Allah berfirman:

"Allah tidak membebani seseorang melainkan sesuai dengan kesanggupannya. Dia mendapat (pahala) dari (kebajikan) yang dikerjakannya dan dia mendapat (siksa) dari (kejahatan) yang diperbuatnya. (Mereka berdoa), "Ya Tuhan kami, janganlah Engkau hukum kami jika kami lupa atau kami melakukan kesalahan. Ya Tuhan kami, janganlah Engkau bebani kami dengan beban yang berat sebagaimana Engkau bebankan kepada orang-orang sebelum kami. Ya Tuhan kami, janganlah Engkau pikulkan kepada kami apa yang tidak sanggup kami memikulnya. Maafkanlah kami, ampunilah kami, dan rahmatilah kami. Engkaulah pelindung kami, maka tolonglah kami menghadapi orang-orang kafir."(QS. Al-Baqarah: 286)

Insaniyah syariah Islam juga bermakna bahwa semua tujuan (maqashid), manfaat dan hikmah syariah dalam rangka mewujudkan kebaikan, rahmat dan kemaslahatan (mashlahah) bagi manusia seluruhnya dan menghindarkan manusia dan lingkungannya dari kejahatan, kezaliman dan kerusakan (mafsadat) di dunia dan akhirat. Tidak ada ajaran dan nilai-nilai syariah sedikitpun yang bertentangan dengan maslahat manusia dan lingkungannya. Allah berfirman: "Dan dalam syariah qisas itu ada (jaminan) kehidupan bagimu, wahai orang-orang yang berakal, agar kamu bertakwa". (QS. Al-Baqarah: 179). "Dan Kami tidak mengutus engkau (Muhammad) melainkan untuk (menjadi) rahmat bagi seluruh alam". (QS. Al-Anbiya: 108).

Dalam riwayat Abu Shaleh, Nabi Saw bersabda: "Wahai manusia, sesuangguhnya aku adalah rahmat yang memberi petunjuk" (HR. At-Thabrani, Ad-Darimi dan Al-Hakim. Dishahihkan oleh At-thabrani dan Al-Hakim). Dalam hadits lain riwayat Abu Hurairah RA, Nabi SAW besabda: "Sesungguhnya aku tidak diutus menjadi tukang laknat, melainkan aku diutus untuk menjadi rahmat" (HR. Muslim dan Ahmad).

\section{c. Mendunia (al-alamiyah)}

Yang dimaksud dengan mendunia atau global (al-alamiyah) adalah, bahwa syariah Islam bersifat mendunia, tidak dibatasi oleh geografi wilayah tertentu, suku, ras dan bangsa tertentu atau iklim serta geopolitik tertentu. Syariah Islam berlaku untuk seluruh alam dan seluruh manusia yang mau menerimanya. Tidak ada perbedaan antara tujuan dan ajaran syariah di Arab dengan diluar Arab atau sebaliknya, tidak ada perbedaan keyakinan umat Islam 
terhadap syariah bahwa dia bersumber dari Allah dan untuk maslahat seluruh alam dimanapun mereka berada.

Tidak ada perbedaan pengamalan pokok-pokok syariah (ushul) kecuali dalam masalah cabang dan rantinya (furuiyah) dimanapun umat Islam berada di kolong dunia ini. Tidak ada perbedaan diantara umat Islam dunia dalam pelaksanaan ibadah, muamalah, hukum dan moralitasnya.

Globalisasi (alamiyah) syariah Islam mengajarkan persaudaraan dunia antara manusia lintas golongan-golongan, suku bangsa dan bahasanya. Syariah Islam mengajarkan tolong menolong global antara manusia dan memelihara lingkungannya. Sebaliknya syariah Islam mengharamkan permusuhan antara manusia dimanapun mereka berada di dunia ini tanpa memandang suku, ras, agama, warna kulit dan bangsanya selama tolong menolong itu untuk kebaikan dan maslahat manusia. Allah berfirman:

"Wahai manusia! Sungguh, Kami telah menciptakan kamu dari seorang laki-laki dan seorang perempuan, kemudian Kami jadikan kamu berbangsa-bangsa dan bersuku-suku agar kamu saling mengenal. Sesungguhnya yang paling mulia di antara kamu di sisi Allah ialah orang yang paling bertakwa. Sungguh, Allah Maha Mengetahui, Maha Teliti. (QS. Al-Hujurat: 13).

"Dan tolong-menolonglah kamu dalam (mengerjakan) kebajikan dan takwa, dan jangan tolong-menolong dalam berbuat dosa dan permusuhan. Bertakwalah kepada Allah, sungguh, Allah sangat berat siksaan-Nya". (QS. Al-Maidah: 2).

Globalisasi syariah Islam bermakna bahwa syariah Islam untuk diperuntukkan untuk seluruh manusia dan seluruh alam semesta, rahmat globalisasi Islam adalah rahmat seluruh alam dan seluruh lingkungan manusia. Negeri Islam adalah semua negeri yang telah dan akan dikumandangkan Laa Ilaaha Illallah (tidak ada Tuhan selain Allah). Karena syariah ini berasal dari Tuhan semesta Alam, Allah Subhanahu wata'ala. Oleh karenanya Nabi umat Islam adalah Nabi dan Rasul untuk semua manusia dan seluruh alam semesta.

"Dan Kami tidak mengutus engkau (Muhammad) melainkan untuk (menjadi) rahmat bagi seluruh alam". (QS. Al-Anbiya: 108). "Dan Kami tidak mengutusmu wahai Muhammad kecuali untuk seluruh manusia" (QS.)

\section{d. Komprehensif (as-syumul)}

Komprehensif atau syumul adalah keseluruhan atau totalitas ajaran syariah Islam, meliputi seluruh atau semua aspek kehidupan manusia di dunia dan akhirat. Syariah Islam tidak menerima dan mengenal pembagian atau pembatasan ajarannya pada dimensi atau bidang tertentu dalam kehidupan manusia, karena syariah Islam berasal dan bersumber dari Tuhan yang Maha Sempurna Allah SWT. Syariah Islam adalah syariah yang mengatur dan membimbing kehidupan manusia di dunia dan akhirat, bahkan aspek ajaran syariah yang paling tinggi dan besar adalah aspek akhirat yang dikenal dengan aspek ibadah. Aspek kedua adalah muamalah yang mengatur kehidupan manusia dengan manusia dan hubungan manusia dengan lingkunngannya. Inilah karakteristik syariah Islam yang komprehensif secara vertikal dan horizontal. Firman Allah: "Pada hari ini telah Aku sempurnakan agamamu untukmu, dan telah Aku cukupkan nikmat-Ku bagimu, dan telah Aku ridhai Islam sebagai agamamu". (QS. Al-Maidah: 3) 
Syariah Islam dalam bentuk Ibadah membimbing manusia dalam berinteraksi dengan Allah SWT secara sempurna dan totalitas, tidak menyisakan sedikitpun dari dimensi dirinya, waktunya, pikirannya, akalnya, hatinya, emosional, psikologis, jiwanya, fisiknya atau lahir dan bathin kecuali hanya untuk Allah SWT ${ }^{10}$. Inilah pengertian dan hakikat ibadah dalam syariah Islam. Allah berfirman: "katakana wahai Muhammad sesusngguhnya shalatku, manasikku hidup dan matiku hanya untuk Allah Tuhan semesta alam" (QS.).

Demikian pula syariah Islam dalam bentuk muamalah mengatur dan membimbing secara sempurna dan lengkap semua dimensi interaksi hidup antar manusia dan lingkungannya. Mumalah Islamiyah adalah muamalah komprehensif dan menyeluruh, meliputi semua aspek politik, ekonomi, budaya, sosial, pendidikan keluarga, hankam, teknologi dan semua aspek kehidupan manusia lainnya, tanpa terkecuali. Allah berfirman: "kami tidak melupakan dalam Al-Qur'an segala sesuatu" (QS. ). Oleh karenanya syariah Islam relevan untuk semua profesi apapun yang digeluti manusia di dunia ini.

Syumuliyah syariah Islam bermakna bahwa syariah ini ditujukan dan terapkan untuk semua jenis kelamin dan fase hidup manusia, laki dan perempuan, anak-anak, remaja, dewasa dan orang tua, masa sulit dan masa lapangnya. Walaupun terdapat penyikapan syariah yang berbeda-beda pada usia dan kondisi tertentu dalam hidup manusia. Syariah Islam menyiapkan semua aturan dan konsep hidup untuk semua jenis kelamin manusia, usia dan fase kehidupannya secara adil, proporsional, seimbang dan menyeluruh. Allah berfirman: Allah telah menjadikan kalian dari lemah, tua..(QS. Lukman)

Syumuliyah syariah Islam bermakna mengatur semua dimensi diri manusia dalam hubungannya dengan Allah SWT (ibadah) dan mengatur serta membimbing dan membina seluruh aspek kehidupan manusia dengan manusia lainnya dan lingkungannya (muamalah) secara integral, seimbang dan bersinergi. Sehingga bidang ibadah tidak menjadi penghalang atau pengurang bidang muamalah, ibadah tidak mendistorsi dan menzalimi muamalah demikian pula sebaliknya. Keduanya berjalan secara harmonis dan bersinergi.

Syumuliyah syariah Islam juga bermakna, bahwa syariah Islam berlaku dan relevan untuk setiap tempat, waktu dan iklim. Ibadah, muamalah dan hukum Islam relevan dan berlaku kapan saja dan dimana saja, tanpa pembatasan dan diskriminasi. Tidak ada Negara atau bangsa yang lebih superior dalam syariah Islam dari bangsa lainnya. Tidak ada suku, ras dan bangsa tertentu yang dapat mengklaim bahwa ras, suku dan bangsanya lebih Islami, lebih baik dan lebih unggul dari bangsa dan suku lainnya di dunia ini. Karena Allah telah menetapkan bahwa: "Sesungguhnya yang paling mulia di antara kamu di sisi Allah ialah orang yang paling bertakwa".(QS. Al-Hujurat: 13). Jadi yang paling mulia adalah yang paling beriman, bertakwa, lebih konsisten terhadap syariah dan akidahnya.

\section{e. Realistis (al-waqi'iyah)}

Al-Waqi'iyah atau relaistis menurut Al-Qardhawi terkait karakteristik syariah Islam bukan realistis dalam pengertian barat yang terkait dengan filsafat materialisme, yang tidak percaya pada sesuatu kecuali materi dan benda serta dapat dimanfaatkan dengan realistis pragmatis. Tapi yang dimaksud realistis dalam karakteritik syariah adalah "sifat syariat Islam

${ }^{10}$ Lihat Yusuf Al-Qardhawi, Al-Khashais Al-Ammah Lil Islam, (Kairo: Maktabah Wahbah, 2003), hal 95 
yang mampu memahami kondisi alam sesuai dengan hakikat dan wujudnya yang dapat disaksikan oleh manusia, memahami dan mengerti bahwa kondisi hidup manusia adalah ciptaan Allah SWT dan berasal dari-Nya dan seterusnya" ${ }^{11}$.

Al-Waqi'iyah adalah karakter syariah Islam yang bermakna bahwa syariah Islam mengajarkan manusia untu mampu memahami dan memaklumi dengan realistis, bahwa manusia adalah ciptaan Allah, tidak ada zat lain yang menciptakannya, sesuai dengan kondisi riil dan ilmiah yang tidak terbantahkan oleh akal dan logika manapun di dunia. Bahwa seluruh makhluk termasuk manusia adalah hamba Allah, Dia yang menciptakan dan mengaturnya serta membimbingnya, kecuali yang ingkar dan memusuhi-Nya.

Al-Waqi'iyah bermakna bahwa syariah Islam adalah syariah yang mengerti dan memelihara keadaan fitrah dan kodrat manusia sebagai makhluk yang lemah dan terbatas, sehingga pemilik syariah (Allah SWT) memberikan kemudahan, keluwesan dan kebijakan yang mengakomodir kondisi riil manusia dalam melaksanakan syariah-Nya atau perintah dan larangan-Nya. Allah berfirman: "Allah hendak memberikan keringanan kepadamu, karena manusia diciptakan (bersifat) lemah". (QS. An-Nisa: 28).

Waqi'yah syariah Islam dalam Ibadah telah melahirkan hukum-hukum keringanan (rukhshah), dan pemakluman (al-l'fa) dan sebagainya kepada manusia, ketika manusia tidak mampu melaksanakannya karena kondisi-kondisi tertentu. Allah tidak memaksakan puasa di bulan ramadhan, bagi mereka yang musafir, sakit dan melahirkan, karenan kondisinya yang lemah dan sulit, Allah tidak memaksakan zakat bagi muslim yang hartanya belum sampai nishab, Allah tidak memaksakan haji bagi mereka yang tidak mampu membiayai perjalanan dan bekal keluarganya, padahal itu semua adalah rukun Islam yang wajib, dimana Islam dibangun dengan nya. Sesuai ayat-ayat berikut:

"Bulan Ramadan adalah (bulan) yang di dalamnya diturunkan Al-Qur'an, sebagai petunjuk bagi manusia dan penjelasan-penjelasan mengenai petunjuk itu dan pembeda (antara yang benar dan yang batil). Karena itu, barangsiapa di antara kamu ada di bulan itu, maka berpuasalah. Dan barangsiapa sakit atau dalam perjalanan (dia tidak berpuasa), maka (wajib menggantinya), sebanyak hari yang ditinggalkannya itu, pada hari-hari yang lain. Allah menghendaki kemudahan bagimu, dan tidak menghendaki kesukaran bagimu. Hendaklah kamu mencukupkan bilangannya dan mengagungkan Allah atas petunjuk-Nya yang diberikan kepadamu, agar kamu bersyukur". (QS. Al-Baqarah: 185).

"Makanlah buahnya apa-bila ia berbuah dan berikanlah haknya (zakatnya) pada waktu memetik hasilnya, tapi janganlah berlebih-lebihan. Sesungguhnya Allah tidak menyukai orang-orang yang berlebihan". (QS. Al-An'am: 141).

"Dan (di antara) kewajiban manusia terhadap Allah adalah melaksanakan ibadah haji ke Baitullah, yaitu bagi orang-orang yang mampu mengadakan perjalanan ke sana. Barangsiapa mengingkari (kewajiban) haji, maka ketahuilah bahwa Allah Mahakaya (tidak memerlukan sesuatu) dari seluruh alam". (QS. Ali Imran: 97).

11 Ibid, hal 144 
Waqi'iyah syariah Islam dapat dilihat dengan jelas dalam keringanan hukum dari Allah SWT terhadap makanan dan minuman yang tadinya diharamkan bagi para mukallaf (objek hukum) seperti bangkai, babi, darah, khamar dan sebagainya. Namun ketika seorang muslim dalam kondisi emergensi atau darurat, yaitu kelaparan atau kehausan yang dapat mengancam jiwa dan fisiknya, dimana tidak ada makanan dan minuman selain yang haram, maka saat itu pula Allah membolehkan makan minum yang hara tersebut. Allah berfirman:

"Sesungguhnya Dia hanya mengharamkan atasmu bangkai, darah, daging babi, dan (daging) hewan yang disembelih dengan (menyebut nama) selain Allah. Tetapi barangsiapa terpaksa (memakannya), bukan karena menginginkannya dan tidak (pula) melampaui batas, maka tidak ada dosa baginya. Sungguh, Allah Maha Pengampun, Maha Penyayang". (QS. AlBaqarah: 173).

Waqi'iyah syariat Islam dapat dilihat dari dimensi muamalah, Allah SWT dan Rasul-Nya menjadikan semua syariah dalam bentuk muamalah, seperti ekonomi, bisnis, politik, pendidikan dan sebagainya, yang terkait hubungan antar masyarakat, Negara dan hubungan social lainnya, hukum asalnya adalah boleh. Hal ini untuk mengakomodir kondisi manusia. Kaidah figh yang terkenal dalam masalah ini menyebutkan "Hukum asal muamalah adalah boleh, sebelum ada dalil yang mengharamkannya".

Waqi'iyah syariah Islam dapat juga dilihat dari segi penegakkan hukum, seorang yang membunuh orang lain dihukum qishas (setimpal), namun ketika keluarga korban memaafkannya, maka hukum atasnya diabaikan. Seorang pencuri di masa Umar bin Khattab RA, tidak dik-hukum karena kondisi orang yang mencuri tersebut sangat miskin dan benarbenar terbukti bahwa dia tidak punya makanan dan terdesak mencuri untuk melanjutkan hidupnya. Deikian sterusnya, syariah Islam adalah syariah yang realistis dan memelihar kondisi lemah dan terbatas manusia.

\section{f. Toleransi dan Memudahkan (as-samhah dan at-taisir)}

As-Samhah adalah memudahkan atau toleransi kepada orang lain ${ }^{12}$. Adapun at-taisir adalah kemudahan dan keringanan ${ }^{13}$. Ibnu Manzur hampir menyamakan makna as-samhah dan at-taisir yaitu kemudahan. Ibnu Asyur memaknai as-samahah adalah kemampuan berinteraksi dengan mudah dan proporsional, atau sikap pertengahan antara memudahmudahkan dan mempersulit"14.

Syariah Islam adalah syariah yang sangat menghindari kesulitan bagi umat manusia dalam memahami dan mengimplementasikannya. Sehingga tidak ada ranah syariah Islam yang sulit kecuali dimudahkan oleh Allah SWT. Ini bukan berarti semua ajaran syariah Islam seluruhnya mudah, karena itu tidak sesuai logika manusia, sebab sulit dan mudah dua hal yang ditakdirkan Allah SWT kepada makhluk-Nya, juga kepada syariatnya. Sebagaimana Allah mentakdirkan ada yang kaya dan ada yang miskin, siang dan malam dan sebagainya. Toleransi dan kemudahan yang dimaksud di sini adalah bahwa Allah SWT menjadikan ajaran syariat-Nya selalu membolehkan memilih yang termudah dan terbaik baik hamba-Nya bukan yang sulit

\footnotetext{
12 Ibnu Manzur, Lisanul Arab, Kairo: Daarul Hadits, 2003, vol 4, hal 673

13 Ibid, vol 9, hal 452

14 Ibnu Asyur, Maqashid Syariah Islamiyah, hal 58
} 
dan buruk, Allah selalu membolehkan pilihan yang toleran dan tidak memberatkan bagi seluruh mukallaf. Allah SWT selalu menyertakan kemudahan kepada hamba-Nya ketika mereka menghadapi kesulitan dalam melaksanakan perintah-Nya dan dalam menghadapi kehidupan mereka sehari. Allah berfirman:

"Allah menghendaki kemudahan bagimu, dan tidak menghendaki kesukaran bagimu". (QS. AlBaqarah: 185)

"Allah tidak ingin menyulitkan kamu, tetapi Dia hendak membersihkan kamu dan menyempurnakan nikmat-Nya bagimu, agar kamu bersyukur". (QS. Al-Maidah: 6)

"Dia telah memilih kamu, dan Dia tidak menjadikan kesulitan untukmu dalam agama. (Ikutilah) agama nenek mo-yangmu Ibrahim. Dia (Allah) telah menamakan kamu orang-orang muslim sejak dahulu, dan (begitu pula) dalam (Al-Qur'an) ini, agar Rasul (Mu-hammad) itu menjadi saksi atas dirimu dan agar kamu semua menjadi saksi atas segenap manusia". (QS. Al-Haj: 78)

"Maka sesungguhnya beserta kesulitan ada kemudahan. sesungguhnya beserta kesulitan itu ada kemudahan". (QS. Al-Insyirah: 6-7).

Dari Ibnu Abbas RA, Nabi SAW bersabda: "Agama yang paling dicintai oleh Allah adalah yang lurus dan mudah (Al-Hanafiyah As-Samhah)"(HR. Bukhari). Nabi SAW bersabda kepada Ali bin Abi Thalib dan Muaz bin jabal ke Yaman: "Kalian mudahkanlah dan jangan persulit umat, berikanlah kabar gembira dan jangan membuat mereka lari/menghindar"(HR. Bukhari). Nabi SAW bersabda kepada para Sahabatnya, ketika seorang Badui kencing di masjid: "Sesungguhnya aku diutus kepada kalian untuk memudahkan bukan untuk menyulitkan atau menyusahkan" (HR. Bukhari).

Oleh karenanya syariah Islam sangat menghindari pemahaman radikal, keras dan intoleran kepada orang lain. Syariah Islam selalu menghendaki kemudahan dan pilihan-pilihan yang mudah, bukan pilihan-pilihan yang sulit dan susah serta merepotkan. Inilah karakter utama syariah Islam sebagaimana ini adalah karakter utama wasathiyah Islam.

Demikian pula sifat toleran adalah karakter utama syariah Islam. Nabi dan para Sahabat memahami dan mengamalkan syariah Islam dalam posisi toleran dan menerima perbedaan. Telah terjadi di antara para sahabat Nabi perbedaan pendapat tentang suatu masalah dalam syariah dan mereka saling toleran atas pendapat masing-masing (khilaf tanawu'), tanpa memaksakan pendapat kecuali pada masalah benar salah, petunjuk dan hidayah, halal dan haram atau yang dikenal dengan pebedaan yang bertentangan (khilaf mudhad). Para ahli sejarah seperti Ad-Zahabi, Ibnu Katsir, At-Thabari, As-Suyuthi dan lainnya menulis dalam sejarah mereka tentang perbedaan pandangan antara sahabat bahkan antara Nabi SAW dan sahabat.

\section{g. Antara Konstanitas dan Fleksibilitas (as-tsawabit dan al-mutaghayirat)}

Karakter terakhir dari syariah ini adalah as-tsawabit dan al-mutaghayirat, yaitu karakter syariah Islam yang terklasifikasi dengan indah dan penuh hikmah dan rahasia tinggi dari Allah, syariah yang tergolong konstan ajeg dan abadi tidak akan pernah berubah, seperti seluruh jenis rukun iman dan rukun Islam. Juga ajaran-ajaran pokok akhlak serta hal-hal yang 
telah diharamkan oleh Allah secara pasti (qath'iy) adalah tsawabit yang tidak menerima ijtihad dan pembaruan. Syariah Islam ada juga yang tergolong mutaghayirat adalah semua hal yang terkait dengan sarana dan prasarana, motode dan srategi, media dan alat, cara dan teknik selain pokok agama (ushul ad-din), semuanya adalah mutaghayirat yang dapat meyesuaikan tempat dan waktu, fleksibel sesuai dengan kondisi manusia dan lingkungannya. Sehingga dengan karakter ini Islam tetap menjadi syariah yang orisinil dan autentik dalam waktu yang sama syariah Islam juga relevan dan sesuai untuk setiap zaman dan tempat. Pembahasan tentang tsawabit dan mutaghayirat ini tidak dibahas dengan luas, kerena teah dibahas sebelumnya dan akan dibahas pada pembahasan tema-tema berikutnya.

\section{Tujuan dan Pembagian Maqashid Syariah}

Bila tujuan Allah menurunkan syariah secara umum adalah mewujudkan kebaikan (maslahat) bagi seluruh manusia dan alam semesta dan menghindarkannya dari kerusakan (mafsadat), maka tujuan Allah menetapkan syariah khusus kepada hamba-Nya dalam bentuk perintah dan larangan adalah untuk kemaslahatan mereka dunia dan akhirat. Sepakata para Ulama seperti Imam Haramain Al-Juwaini, Imam Al-Gazali, Imam Ar-Razi dan Imam Al-Amidi dan As-Syatibiy ${ }^{15}$ menyepakati bahwa klasifikasi tujuan syariah dan maslahat manusia dalam semua agama yang diturunkan oleh Allah kepada manusia selalu bermuara pada 5 (lima) tujuan utama Syariah, yaitu sesuai urutan yang disepakati oleh Al-Ghazali dan Al-Amidi adalah: memelihara agama, memelihara jiwa, memelihara akal, memelihara keturunan dan memelihara harta"16.

Adapun pembagian atau klasifikasi tujuan syariah menurut para ulama adalah dibagi menjadi 3 (tiga) bagian utama:

\section{Tujuan syariah yang bersifat emergensi atau mendesak yang dikenal dengan dharuriyaat.}

Bagian ini harus dan wajib dijaga dan direalisasikan untuk kehidupan dunia dan akhirat, bila tidak akan menimbulkan kerusakan, kebinasaan bahkan kesengsaraan dunia dan akhirat. Contoh dalam masalah ini adalah mengucap syahadat, shalat 5 waktu, puasa, zakat dan haji dalam rangka memelihara agama. Kewajiban mengkonsumsi makanan dan minuman halal lagi baik, pakaian, menikah, tempat tinggal yang layak dan seterusnya dalam rangka memelihara jiwa, keturunan, dan akal manusia ${ }^{17}$.

\section{Tujuan syariah yang bersifat kebutuhan dan keperluan sehari-hari manusia (hajiyat).}

Bila tujuan ini tidak terpenuhi, akan menimbulkan kesulitan dan kesempitan hidup namun tidak sampai pada level merusak dan membinasakan maslahat hidup seseorang secara umum. Dalam masalah ibadah contohnya adalah keringanan (rukhshah) dalam ibadah seperti, boleh berbuka puasa saat musafir. Dalam masalah kebiasaan hidup manusia dibolehkannya

\footnotetext{
15 Abu Ishak As-Syathibiy, Al-Muwafaqaat, vol 2, hal 7

${ }^{16}$ Ali bin Muhammad Al-Amidi, Al-Ihkam fi Ushulil Ahkam, vol 3, (Beirut: Al-Maktab Al-Islami, Cet. Ke

$2,1402 \mathrm{H})$, hal 252

17 Abu Ishak As-Syathibiy, Al-Muwafaqat fii Ushul As-Syariah, (Kairo: al- maktabah at-taufiqiyah, 2003), vol 2 , hal 8
} 
berburu, menikmati yang baik-baik dan halal. Dalam masalah muamalat bolehnya melakukan akad salam, jual-beli, murabahah dan sebagainya"18.

\section{Tujuan syariah yang bersifat aksesoris dan pelengkap (tahsiniyat)}

Aksesoris atau Tahsiniyat adalah menggunakan sesuatu yang layak menurut adat atau kebiasaan manusia dan meninggalkan sesuatu yang tidak layak, tidak pantas yang bertentangan dengan akhlak atau moralitas secara umum. Contoh dalam masalah ini diantaranya adalah: membersihakn diri dari najis, memakai perhiasan, melaksanakan ibadahibadah sunnah, sedeqah dan amal-amal kebaikan lainnya yang tidak wajib dan sebagainya” ${ }^{\prime 19}$.

Menurut As-Syatibiy semua tujuan syariah dalam kehidupan manusia ini ada yang telah disebutkan langsung oleh Allah SWT, ketika menetapakan perintah atau kewajiban dan larangan kepada hamba-hamba-Nya, ada yang tidak disebutkan secara langsung oleh Allah SWT. Maka dari itu membutuhkan usaha atau ijtihad para ulama atau fuqaha dalam menetapkan tujuan suatu perintah atau larangan tersebut berdasarkan alasan-alasan (illat) yang tersirat dalam sebuah nash atau syariah. Tujuan syariah yang telah disebutkan langsung oleh Allah SWT ketika mensyariahkan sesuatu sangat banyak dalam AI-Qur'an, seperti tujuan Allah memerintahkan berwudhu adalah untuk membersihkan diri dan menyucikan manusia. Allah befirman: "Allah tidak ingin menyulitkan kamu, tetapi Dia hendak membersihkan kamu dan menyempurnakan nikmat-Nya bagimu, agar kamu bersyukur". (QS. Al-Maidah: 6). Tujuan Allah mewajibkan ibadah puasa adalah untuk menjadikan manusia bertakwa pada-Nya. Firman Allah: "Wahai orang-orang yang beriman! Diwajibkan atas kamu berpuasa sebagaimana diwajibkan atas orang sebelum kamu agar kamu bertakwa". (QS. Al-Baqarah: 183), tujuan Allah SWT mewajibkan Shalat 5 (lima) waktu adalah agar manusia terhindar dari perbuatan keji dan merusak. Allah berfirman: "Bacalah Kitab (Al-Qur'an) yang telah diwahyukan kepadamu (Muhammad) dan laksanakanlah shalat, sesungguhnya shalat itu mencegah dari (perbuatan) keji dan mungkar". (QS. Al-Ankabut: 45) dan seterusnya"20.

\section{E. Urgensi Maqashid Syariah dalam memahami Islam}

Oleh karena itu, memahami syariah dan memahami nash-nash syariah agar dapat diamalkan dengan benar dan tepat dalam kehidupan umat, harus memahami ilmu maqashid syariah, sebab tidak mungkin seorang ulama memahami kandungan sebuah nash syariah dan maksudnya atau tujuannya tanpa mengetahui ilmu ini. Tidak dapat dipungkiri, saat ini banyak ulama atau Da'I memberikan fatwa kepada umat yang melahirkan kontroversi dan keresahan disebabkan tidak memperhatikan maqashid syariah dalam fatwa mereka. Berikut adalah beberapa urgensi maqashid syariah:

1. Mampu memahami dan menetapkan tujuan dan maksud syariah yang ada dalam AlQur'an dan As-Sunnah

2. Mampu menetapkan fatwa atau hukum dari sebuah nash Al-Qur'an dan As-sunnah yang masih bersifat umum sesuai dengan maksud pembuat syariah/Allah SWT.

\footnotetext{
18 Ibid, hal 9

19 Ibid

20 Ibid, hal 4
} 
3. Mampu menganalogikan (mengkiaskan) suatu hukum terhadap suatu masalah yang belum ada hukumnya dalam Al-Qur'an dan As-sunnah atau ljma', dengan masalah yang telah ada hukumnya dalam Al-Qur'an dan As-Sunnah ${ }^{21}$.

4. Mampu mengeluarkan hukum-hukum praktis terhadap suatu masalah baru yang dihadapi umat dari dalil-dalil Al-Qur'an dan As-sunnah yang bersifat global atau umum ${ }^{22}$.

5. Mampu menjawab seluruh problematika umat khususnya dalam masalah hukum Islam atau hukum-hukum ibadah dan muamalah yang masih diperselisihkan para ulama, atau kasus-kasus hukum syariah yang bersifat kontenporer karena belum ada dalilnya dalam Al-Qur'an, As-Sunnah dan ljma'.

6. Mampu memahami dan bersikap bijak dan adil dalam menyikapi perbedaan pendapat para ulama terhadap satu masalah dan memberikan solusi yang moderat dan proporsional

7. Bagi umat Islam, maqashid syariah dapat memberikan jawaban dan solusi yang syar'iy dan ilmiah terhadap setiap kasus, masalah dan tantangan umat di setiap zaman.

\section{F. Hubungan Maqashid Syariah dan Moderasi Islam}

Hubungan Maqashid Syariah dengan Moderasi Islam, adalah hubungan yang sangat kuat dan saling memengaruhi. Mengapa demikian? Karena moderasi Islam selalu memperhatikan dan diikat dengan tujuan dan hikmah Syariah secara umum. Tidak ada moderasi, keadilan, keseimbangan dan konsistensi dalam syariah tanpa maqashid syariah, sebaliknya setiap hukum dalam Islam akan mengandung moderasi, keadilan dan maslahat bagi umat, bila berlandaskan maqashid syariah.

\section{Maqashod Syariah mewujudkan moderasi dalam syariah}

Maqashid syariah yang mengajarkan bagaimana memahami teks-teks syariah dengan mencari maksud, tujuan dan hikmah ditetapkannya sebuah hukum dalam Al-Qur'an dan AsSunnah kepada mukallaf, akan mewujudkan moderasi (wasathiyah) dalam semua ajaran Islam. Hal ini dapat dilhat dengan jelas dalam ijtihad dan fatwa yang terkait dengan masalah ibadah, muamalah dan sebagainya.

\section{Maqashid Syariah mewujudkan moderasi dalam ljtihad dan Fatwa}

Bila setiap mujtahid atau mufti mampu memahami dengan baik maqashid syariah, maka produk hukum dan ijtihadnya atau hasil fatwanya akan mewujudkan keadilan, sikap pertengahan dan proporsionalisme (moderat). Sebab maqashid syariah adalah kemampuan mengenal dan menentukan tujuan dan rahasia pembuat syariah dalam menetapkan hukum bagi manusia. Karena Allah SWT sebagai pembuat dan penetap hukum syara' (as-syari') bagi manusia, sangat menginginkan keadilan dan kemudahan bagi hamba-Nya. Allah berfirman: "Allah menghendaki kemudahan bagimu, dan tidak menghendaki kesukaran bagimu". (QS. AlBaqarah: 185). "Itulah ayat-ayat Allah yang Kami bacakan kepada kamu dengan benar, dan Allah tidaklah berkehendak menzhalimi (siapa pun) di seluruh alam". (QS. Ali Imran: 108), dan banyak lagi ayat lainnya.

\footnotetext{
21 At-Thahir bin Asyur, Maqashid As-Syariah Al-Islamiyah, hal 13

22 Ibid, hal 13
} 
Maqashid syariah akan menghindarkan seorang muslim berfatwa tanpa IImu dan wawasan yang luas tentang sebuah dalil, sebagaimana banyak terjadi di masa ini. Sering seorang da'l atau ustadz berfatwa kontroversial dan meresahkan umat, karena mengharamkan yang halal dan menghalalkan yang haram, disebabkan tidak mengetahui maksud syariah ini.

\section{Maqashid Syariah mewujudkan moderasi dalam Ibadah}

Seorang Ulama, Da'I dan muslim akan memahami dan melaksanakan selurauh ibadah dalam Islam dengan moderat (wasathiy) ketika dia mampu memhami maqashid syariah. Dia akan terhindar dari paham dan sikap berlebihan (ghuluw) dalam beragama. Karena dia mengerti bahwa makna beribadah adalah merendahkan diri (At-tazalul) dan menundukkan diri (al-khudhu) pada Allah SWT'23. Dan tujuan Allah SWT membebankan dan mewajibkan ibadah kepada hamba-hamba-Nya adalah agar mereka bertakwa kepada-Nya. Firman Allah: "Wahai manusia! Beribadahlah pada Tuhanmu yang telah menciptakan kamu dan orangorang yang sebelum kamu, agar kamu bertakwa". (QS. Al-Baqarah: 21). Jadi ibadah tidak dilihat dari berlebihan atau menguranginya dari ketentuannya sebagaimana yang telah ditetapkan Allah SWT, tetapi bagaimana keikhlasan dan benarnya ibadah tersebut sesuai syariat dan ikhkas hanya untuk Allah SWT. "Yang menciptakan mati dan hidup, untuk menguji kamu, siapa di antara kamu yang lebih baik amalnya. Dan Dia Mahaperkasa, Maha Pengampun". (QS. Al-Mulk: 2). Fudhail bin lyadh mengomentari ayat ini, berkata: "maksudnya adalah Ikhals hanya karena Allah dan benar sesuai syarat".

\section{Maqashid Syariah mewujudkan moderasi dalam Muamalah}

Maqashid syariah dalam muamalah adalah membolehkan semua bentuk muamalah, selama tidak ada dalil yang mengharamkannya atau melarangnya. Dari sini lahirlah kaidah fiqh yang sangat dikenal: "Hukum asli dari muamalah adalah boleh, kecuali ada dalil yang mengharamkannya". Orang-orang yang memahami maqashid syariah akan memandang sebuah kasus atau masalah muamalah dengan hukum boleh, lalu mencari dan memastikan adanya dalil syara' terhadap masalah tersebut, baik dari Al-Qur'an, As-Sunnah, ljma' dan Qiyas. Sering terjadi seorang Da'l gegabah memutuskan hukum sebuah perkara muamalat, yang ternyata telah ditetapkan oleh salah satu dari sumber dalil syara' seperti, ljma atau qiyas. Fatwa atau pandangan dalam muamalah yang memperhatikan maqashid syariah akan mewujudkan moderasi dalam mumalah, karena hukum asli muamalah yang bersifat boleh, akan memberikan keluasam keluesan dan kemudahan dalam hukum mumalah. Kebutuhan manusia dalam bentuk mumalah sangat luas dan berkembang setiap waktu. Karenanya Rasulullah SAW bersabda dalam masalah muamalah ini memberikan keluasan dan kebebasan kepada umat Islam: "Kalian lebih mengetahui tentang urusan dunia kalian" (HR. Muslim, Ahmad, Ibnu Majah dan Ibnu Hibban).

\section{Penutup}

\footnotetext{
${ }^{23}$ Ibnu Qayim Al-Jauziyah, Madarijus Salikin baina manazil iyyaka na'budu waiyyaka nastain, Kairo: Daarul Hadits, 2003 vol 1, hal 66
} 
Maqashid Sayri'ah adalah alat dan manhaj utama para Fuqaha dalam memahami dan mengeluarkan hukum-hukum fiqh yang dikandung oleh Nash-nash Syari'ah (Al-Qur'an dan AsSunnah. Tanpa mengetahui Maqashid Syari'ah seorang Ulama akan keliru dan salah dalam menentukan hukum sebuah masalah dalam Islam. Oleh karena itu Ilmu Maqashid Syari'ah adalah ilmu yang wajib diketahui oleh para Mahasiswa, para Da'I dan para Ulama dalam memahami Ibadah, Muamalah dan hukum-hukum Islam.

Pemahaman yang baik terhadap Mawaqashid Syari'ah akan memberikan kompetensi dan kemampuan yang baik bagi para Ulama dalam memberikan fatwa tentang hukum-hukum perbuatan Mukallaf khsusunya yang terkait dengan Muamalah, seperti; Jual beli dan Keuangan Syari'ah, Perbankan Syariah, Hukum-Hukum Ibadah dan prakteknya secara umum, sehingga melahirkan paham dan pengamalan serta skipa berlslam yang moderat (wasathiy) tidak ekstrem kanan (Keras dan berlebihan) dan tidak ekstrem kiri (Liberal).

\section{Referensi:}

1. Abu Ishak As-Syathibiy, Al-Muwafaqat fii Ushul As-Syariah, Kairo: al- maktabah attaufiqiyah, 2003

2. Ali bin Muhammad Al-Amidi, Al-Ihkam fi Ushulil Ahkam, Beirut: Al-Maktab Al-Islami, Cet. Ke 2, 1402H

3. Fairuz Abadziy, Al-Qamus Al-Muhith, Beirut: Muassasah Ar-Risalah, tt

4. Ibnu Manzur, Lisanul Arab, Kairo: Daarul Hadits, 2003

5. Ibnu Qayim Al-Jauziyah, Madarijus Salikin baina manazil iyyaka na'budu waiyyaka nastain, Kairo: Daarul Hadits, 2003

6. Mahmud Syalthut, Al-Islam Akidah Wa Syariah, Kairo: Dar As-Syuruq, cet ke-19, 2001

7. Manna' Al-Qathan, At-Tasyri' wal Fiqh Al-Islamiy, Beirut: Muassasah Ar-Risalah, cet. Ke-8, 1987

8. Muhammad Abdul Athi Muhammad Ali, Al-Maqashid As-Syar'iyah watsaruha fil fiqhil Is/ami, Kairo: Darul Hadits, 2007

9. Muhammad Abdul Athi Muhammad Ali, Al-Maqashid As-Syar'iyah watsaruha fil fiqhil Islami, Kairo: Darul Hadits, 2007

10. Muhammad At-Thahir bin Asyur, Maqashid As-Syari'ah Al-Islamiyah, Kairo: Daar AsSalam, 2006

11. Yusuf Al-Qardahwi, Dirasah fi Fiqh Maqashid Syari'ah, bainal maqashid al-kulliyah wa annusushus al-juz'iyah, Kairo: Dar As-Syuruq, cet ke-2 2007

12. Yusuf Al-Qardhawi, Al-Khashais Al-Ammah Lil Islam, Kairo: Maktabah Wahbah, 2003 